\title{
Groundwater quality on a waste disposal area due to sand mining activities in São Paulo State, Brazil
}

\author{
D. M. Bonotto ${ }^{1}$ \& E. G. de Oliveira ${ }^{2}$ \\ ${ }^{1}$ Departamento de Petrologia e Metalogenia, \\ Instituto de Geociências e Ciências Exatas-UNESP, Rio Claro, Brazil \\ ${ }^{2}$ Departamento de Geologia Aplicada, \\ Instituto de Geociências e Ciências Exatas-UNESP, Rio Claro, Brazil
}

\begin{abstract}
This investigation reports the results of a study realized in an area related to the development of sand mining activities, which belongs to Sibelco Mineração Ltd. The site is located around Analândia municipality, nearly in the center of São Paulo State, Brazil. Hydrochemical analyses of groundwater were realized under different periods of time, with the aim of evaluating the possibility of release of several constituents to the liquid phase, which may be a source of pollution of the surface hydrological resources and of the deeper Guarani aquifer. This is because the site is located at the recharge area of Guarani aquifer and some tributaries from Corumbataí river may also be suffering contamination, implying on the impoverishment of the water quality that are very important resources in the region, as they are extensively used for drinking purposes, among others.

Keywords: sand mining activities, water quality, groundwater, elemental concentrations, trace and heavy metals, São Paulo State.
\end{abstract}

\section{Introduction}

The São Paulo State in Brazil, due to its advanced stage of agricultural and industrial growth, has a great diversity of problems related to the interaction between the society and the environment. The sand mining activities in Depressão Periférica geomorphological province are presently very important, because potentially they can be a source of anthropogenic impacts, since several 
chemicals are used for the treatment of natural sand like $\mathrm{HCl}, \mathrm{H}_{2} \mathrm{SO}_{4}, \mathrm{NaOH}$ and $\mathrm{Na}_{2} \mathrm{SiO}_{4}$, generating mine tailings that can pollute the surface and underground hydrological resources. This study focuses one area belonging to Sibelco Mineração Ltd., located about 5-6 km from Analândia city, nearly in the center of São Paulo State (Fig. 1). The knowledge of the concentrations of dissolved elements and compounds is needed in order to establish their background values and to predict their potential increase in future years. Thus, the purpose of this paper is to compare the values obtained for various parameters in groundwater from the studied area with those defined by the national standards for drinking water.

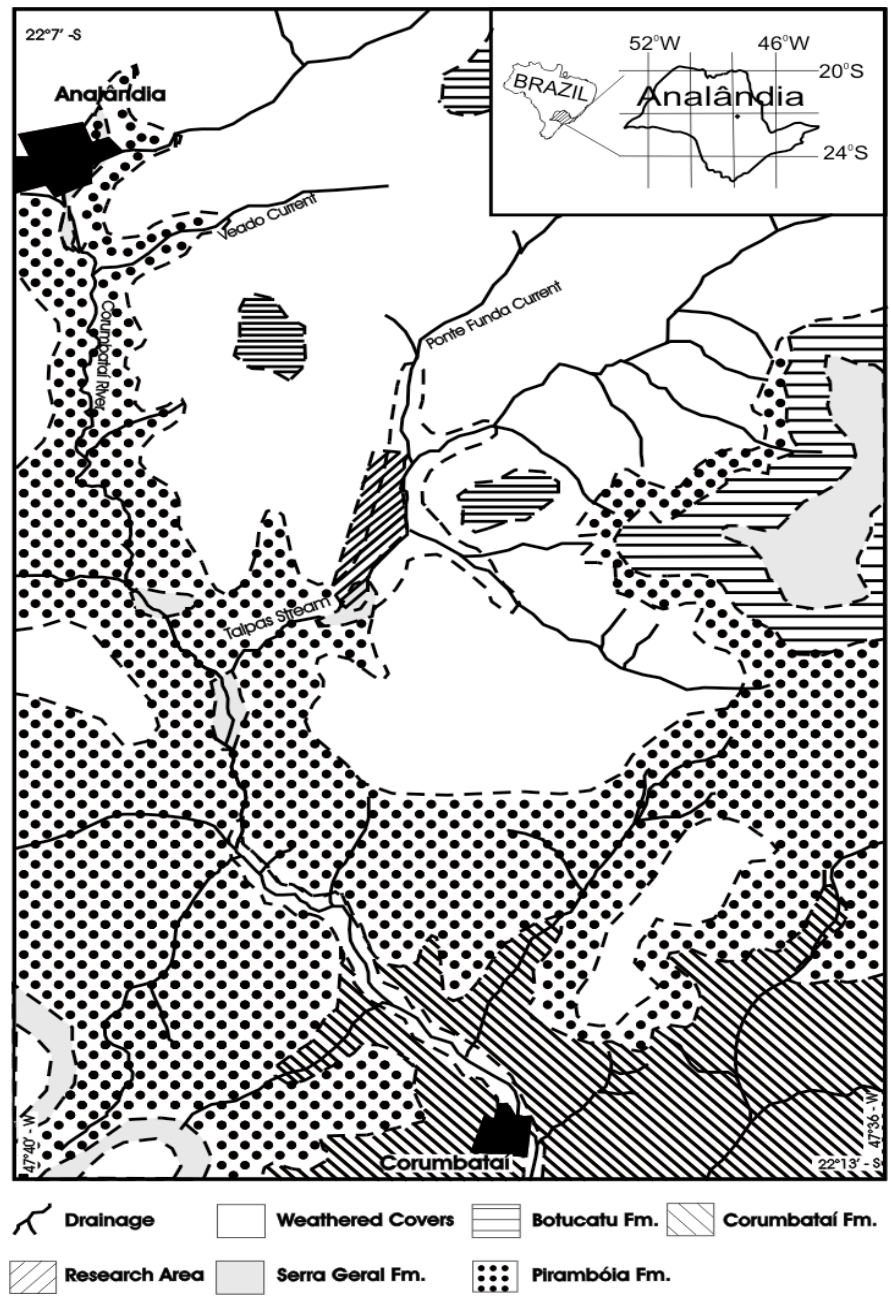

Figure 1: Location of the Analândia city at São Paulo State, Brazil, and simplified geological map of area studied. Modified from [1-3]. 


\section{General features of the area studied}

The area is situated within the Corumbatai river basin that occurs in an eroded belt in the cuestas zone of the Depressão Periférica geomorphological province [4]. The Corumbataí river basin extends over an area of about $1,581 \mathrm{~km}^{2}$. It is a sub-basin of the giant Paraná sedimentary basin, whose area is about $1,000,000$ $\mathrm{km}^{2}$ in Brazilian surface [5]. Several stratigraphic units of the Paraná basin (Paleozoic - Cenozoic) crop-out in it as described by [3], where the main lithologies include: the Lower and Upper units from Pirambóia Formation, the Botucatu Formation and the weathered cover developed over Pirambóia Formation (red-yellow latosols).

The Lower unit from Pirambóia Formation consists of a consolidated whitish sandstone (after washing) with well-preserved sedimentary structures, whose thickness is more than $80 \mathrm{~m}$, the retention after grinding is greater on the 0.125 $\mathrm{mm}$-size sieve, and the Fe oxide mineral content is low. The occurrence of small clay lenses of variable lateral size is very common in this unit. The Upper unit from Pirambóia Formation is a light pink saprolite characterized by thin sedimentary structures and very brittle sandstone located above the water table, whose concentration of Fe oxide is also low and the dominant particle-size after milling is in the range $0.125-0.25 \mathrm{~mm}$.

A 1-30 cm thick stone line profile [6] occurring as an irregular replica of the topography divides the Upper unit from Pirambóia Formation and the above located mantle of weathering, which is constituted by tabular blocks of sandstones cemented by black coloured limonite, dark red ferruginous concretions, small tablets of limonite cementing sandstone, $\mathrm{SiO}_{2}$ pebbles, weathered yellowish sandstone and major concentration of heavy minerals (hematite, magnetite and ilmenite).

The Botucatu Formation is represented in the area by weathered sandstones with high content of $\mathrm{Fe}$ oxide and particle-size predominantly in the range $0.5-1$ $\mathrm{mm}$.

The weathered cover developed over Pirambóia Formation includes: peat soil, creep soil, and soil above the stone line. The peat soil is light grey-black colored, and occurs from the point of the discharge of the water table up to the contour level corresponding to that of the local streams. The creep soil is very clayey $(12-20 \%)$, occurs on the steep ground, being characterized by a red-brownish color, values of $\mathrm{Fe}$ oxide content of about $5000 \mathrm{ppm}$, and presence of limonite concretions between 2 and $6 \mathrm{~m}$ depth. The soil above the stone line is yelloworangish colored, its thickness may attain $18 \mathrm{~m}$, occurs where the ground slope is smooth, has a clay content varying between 7 and 18\%, and a higher Fe oxide content near the surface due to the laterization, which diminishes with increasing depth, rising again at the stone line position.

The area investigated in this study is inserted within the Taipas stream subbasin of the Corumbataí river basin (Fig. 1). The Taipas stream is the main drainage in the area; its name changes to Ponte Funda current, about $1 \mathrm{~km}$ upstream from the sand mining area. Its general flow direction is NE-SW, flowing towards SW up to the confluence with the Corumbataí River. Its average 
discharge is $337.49 \mathrm{~L} / \mathrm{s}$, decreasing approximately $10 \%$ during the drier months. It also controls the groundwater flow as demonstrates the piezometric lines direction characterized by a gradient increase at the channel position (Fig. 2).

The mean ground slope of Taipas stream is $2.0 \%$ and slightly lower $(1.3 \%)$ in front of the sand mining area, where the groundwater flow lines exhibit the following characteristics (Fig. 2): a) hydraulic gradient ranging from $0.10(10 \%$ or $\left.6^{\circ}\right)$ to $0.15\left(15 \%\right.$ or $\left.8^{\circ}\right)$; b) main direction of the flow vectors varying from $\mathrm{N}$ $\mathrm{S}$ to NW-SE.

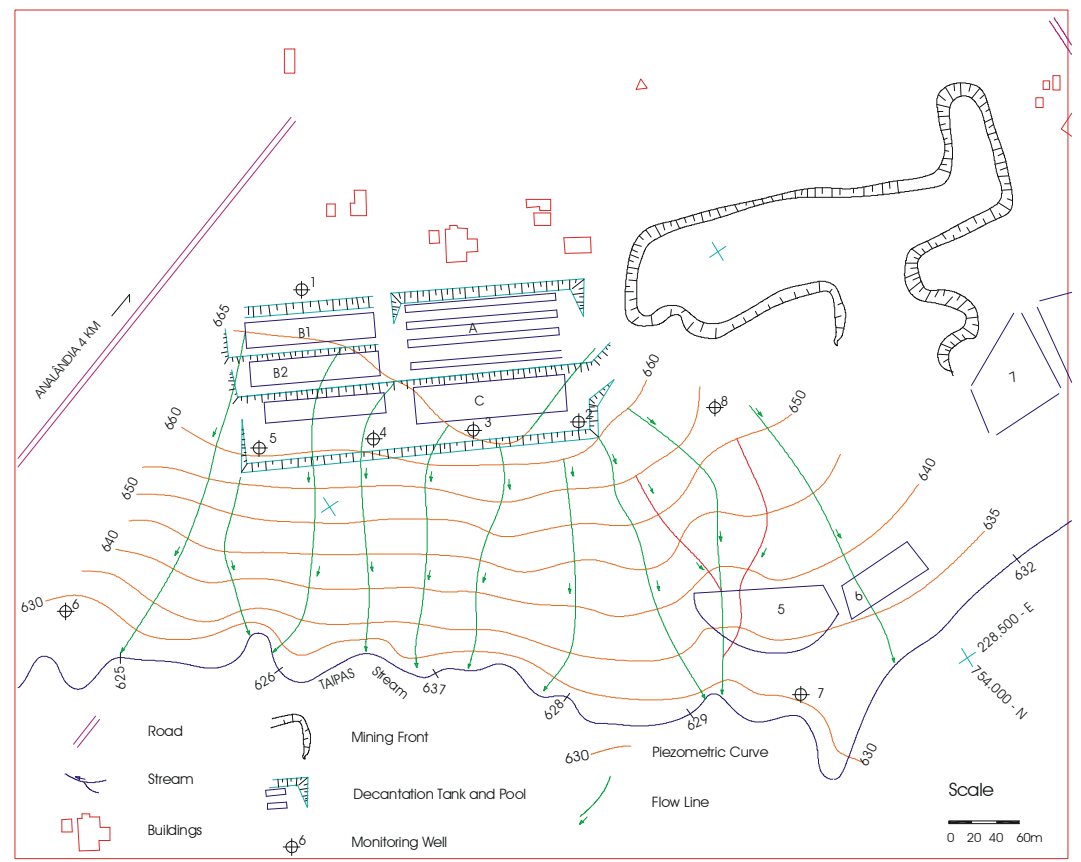

Figure 2: Piezometric map and location of decantation pools and tanks at the studied area.

However, some distortions occur in the groundwater flow lines, mainly between the monitoring wells 2 and 8 , which are caused by two dominant factors:

1. Existence of a fault line that created a more permeable zone in this region, responsible by the water table lowering in monitoring well 8 . Actually, such deformation extends from the area between wells 2 and 8 up to the monitoring well 7, along the fault. This faulting fits the regional pattern despite being masked by the weathered cover developed over Pirambóia Formation.

2. Sedimentary character of the flow net, i.e. it occurs in the Lower unit from Pirambóia Formation that controls its direction. Thus, there is no complete subordination to the hydraulic gradient, but also to the less permeable and more 
compact characters of this unit. This aspect is reinforced by the lower inflexion of the flow lines towards Taipas stream, where occurs the groundwater discharge. The flow lines in Fig. 2 also indicate that the zones of lower altitude (630-650 m) exhibit higher permeability and lower hydraulic gradient than the areas situated at the more elevated altitudes $(650-665 \mathrm{~m})$.

\section{Material and methods}

The groundwater sampling was held in 8 monitoring wells drilled for characterizing the subsurface flow (Fig. 2 and Table 1). The first station was located up-flow of the waste disposal/treatment area, whereas all others were situated down-flow (Fig. 2). Three water sampling campaigns were realized (September 1993, March 1994 and October 1994) in which the samples were stored in polyethylene bottles, and depending on the requirements of the analysis, they were a) unfiltered and unpreserved, b) filtered through $0.45 \mu \mathrm{m}$ membrane and unpreserved and c) filtered and preserved with different acids.

Table 1: Characteristics of the monitoring wells drilled at the studied area.

\begin{tabular}{cccccccccc}
\hline Parameter & Unit & 1 & 2 & 3 & 4 & 5 & 6 & 7 & 8 \\
\hline Diameter & $\mathrm{mm}$ & 100 & 100 & 100 & 100 & 100 & 100 & 100 & 100 \\
Length & $\mathrm{m}$ & 31.0 & 25.9 & 26.2 & 25.2 & 26.3 & 15.7 & 6.7 & - \\
WTD1 $^{\mathrm{a}}$ & $\mathrm{m}$ & 13.99 & 10.38 & 6.17 & 9.62 & 10.01 & 5.41 & 1.25 & - \\
WTD2 $^{\mathrm{a}}$ & $\mathrm{m}$ & 16.90 & 10.40 & 7.32 & 10.80 & 11.45 & 5.00 & 0.50 & - \\
WTD3 $^{\mathrm{a}}$ & $\mathrm{m}$ & 18.90 & 11.70 & 8.80 & 12.70 & 13.70 & 5.80 & 1.15 & 18.30 \\
WLT1 $^{\mathrm{b}}$ & $\mathrm{m}$ & 14.10 & 14.35 & 18.93 & 14.30 & 14.75 & 10.70 & 5.60 & - \\
WLT2 $^{\mathrm{b}}$ & $\mathrm{m}$ & 12.10 & 14.20 & 17.45 & 12.50 & 12.60 & 9.90 & 5.55 & - \\
Water Volume $^{\mathrm{c}}$ & $\mathrm{L}$ & 442.7 & 450.6 & 594.4 & 449.0 & 463.2 & 336.0 & 175.8 & -
\end{tabular}

${ }^{a}$ WTD = Water Table Depth (1-September 1993; 2-March 1994; 3-October 1994);

${ }^{b}$ WLT $=$ Water Layer Thickness (1-March 1994; 2-October 1994); ${ }^{\mathrm{c}}$ March 1994.

Portable meters were used for in situ measurements of temperature, $\mathrm{pH}$, and dissolved oxygen (DO), with the equipment calibration being performed immediately before the analyses. The $\mathrm{pH}$ measurement was performed by a digital portable meter coupled to a combination glass electrode; buffer solutions equilibrated with the sample temperature were utilized to calibrate the equipment before the analyses. The DO was determined in a pointer meter recording the potential values generated by an $\mathrm{O}_{2}$ sensible electrode consisting on a metallic wire covered by a thin layer of gold. A bench digital meter provided electrical conductivity readings obtained though a $1 \mathrm{~cm}^{2}$ area platinum electrode calibrated with $\mathrm{KCl}$ standards.

The settleable solids in each sample were evaluated by a clear borosilicate glass Imhoff cone $0-1000 \mathrm{~mL}$ calibrated. The dry residue (DR) content was evaluated on evaporating the filtrate to dryness in a weighed flask that was dried 
to constant weight at $180^{\circ} \mathrm{C}$, with the increase in flask weight representing DR [7]. The BOD (Biochemical Oxygen Demand) was measured by the dilution method, employing high purity distilled water provided by Barnstead Mega-Pure One Liter Water Still. For this purpose, the dissolved oxygen (DO) content remaining in six portions of each well-mixed sample transferred to different 300$\mathrm{mL}$ glass-stopped bottles was evaluated after a 5-day incubation period. The DO values measured potentiometrically by using a DO probe were plotted against the sample volume taken, yielding a straight line that allowed obtain the BOD data. The chemical oxygen demand (COD) was evaluated by the dichromate reflux method [7], using aliquots acidified to $\mathrm{pH}=2$ with concentrated $\mathrm{H}_{2} \mathrm{SO}_{4}$.

Standard analytical techniques consisting on colorimetry and inductivelycoupled plasma spectrometry were used for determining the following metals in the water samples: $\mathrm{Fe}, \mathrm{Al}, \mathrm{Ca}, \mathrm{Pb}, \mathrm{Mg}, \mathrm{Ni}$ and $\mathrm{Ag}$. The amount of $\mathrm{Pb}, \mathrm{Al}$ and $\mathrm{Fe}$ in the samples collected in September 1993 and March 1994 was estimated colorimetrically by Hach DR/2000 spectrophotometer [8]. Lead ions in basic solution reacted with dithizone to form a pink to red lead-dithizonate complex, extracted with chloroform and read at $515 \mathrm{~nm}$. The aluminon method that utilizes ascorbic acid provided the measurements for aluminum, read at $522 \mathrm{~nm}$. The 1,10 phenanthroline indicator formed an orange color in proportion to the iron concentration, which was read at $510 \mathrm{~nm}$. All other analyses were realized by inductively-coupled plasma spectrometry [9] that exhibits a lower detection limit than colorimetry. Tables 2-4 report the results of the measurements.

Table 2: Analytical data of the groundwater samples collected in 09/06/1993.

\begin{tabular}{ccccccccc}
\hline Parameter & $\mathrm{Unit}$ & 1 & 2 & 3 & 4 & 5 & 6 & 7 \\
\hline Temperature & ${ }^{\circ} \mathrm{C}$ & 30 & 27 & 29 & 29 & 30 & 30 & 26 \\
$\mathrm{DO}$ & $\mathrm{mg} / \mathrm{L}$ & 2.6 & 7.6 & 8.9 & 6.5 & 4.0 & 7.7 & 4.1 \\
$\mathrm{pH}$ & - & 6.85 & 5.95 & 6.30 & 6.07 & 6.17 & 6.13 & 6.42 \\
Conductivity & $\mathrm{\mu S} / \mathrm{cm}$ & 510.0 & 25.1 & 21.1 & 66.2 & 55.0 & 101.9 & 84.4 \\
Iron & $\mathrm{mg} / \mathrm{L}$ & 3.00 & 0.02 & 0.06 & $<0.02$ & $<0.02$ & $<0.02$ & 0.60 \\
Aluminum & $\mathrm{mg} / \mathrm{L}$ & 3.30 & $<0.10$ & $<0.10$ & $<0.10$ & $<0.10$ & $<0.10$ & 2.20 \\
Calcium & $\mathrm{mg} / \mathrm{L}$ & 3.50 & 0.50 & 0.90 & 0.80 & 1.70 & 8.20 & 3.20 \\
Lead & $\mathrm{mg} / \mathrm{L}$ & $<0.10$ & $<0.10$ & $<0.10$ & $<0.10$ & $<0.10$ & $<0.10$ & $<0.10$ \\
Magnesium & $\mathrm{mg} / \mathrm{L}$ & 1.50 & 0.20 & 0.30 & 0.20 & 0.70 & 2.30 & 0.60 \\
Nickel & $\mathrm{mg} / \mathrm{L}$ & $<0.02$ & 0.02 & 0.09 & 0.02 & $<0.02$ & $<0.02$ & $<0.02$ \\
Silver & $\mathrm{mg} / \mathrm{L}$ & $<0.10$ & $<0.10$ & $<0.10$ & $<0.10$ & $<0.10$ & $<0.10$ & $<0.10$ \\
COD & $\mathrm{mg} / \mathrm{L}$ & 36.80 & 18.40 & 9.20 & 9.20 & 9.20 & 27.60 & 9.20 \\
BOD & $\mathrm{mg} / \mathrm{L}$ & 44.75 & 19.00 & 6.84 & 8.68 & 8.30 & 9.52 & 11.36 \\
Dry residue & $\mathrm{mg} / \mathrm{L}$ & 364 & 46 & 28 & 568 & 44 & 62 & 118 \\
Settleable solids & $\mathrm{mg} / \mathrm{L}$ & 47.72 & $<0.01$ & 1.04 & $<0.01$ & 1.20 & 0.03 & 382.93 \\
\hline & & & & & & & &
\end{tabular}


Table 3: Analytical data of the groundwater samples collected in 03/31/1994.

\begin{tabular}{ccccccccc}
\hline Parameter & $\mathrm{Unit}$ & 1 & 2 & 3 & 4 & 5 & 6 & 7 \\
\hline $\mathrm{DO}$ & $\mathrm{mg} / \mathrm{L}$ & 5.1 & 2.0 & 4.8 & 3.7 & 3.5 & 4.1 & 3.2 \\
$\mathrm{pH}$ & - & 6.51 & 5.65 & 5.97 & 6.30 & 6.37 & 5.86 & 6.31 \\
Conductivity & $\mu \mathrm{S} / \mathrm{cm}$ & 356.0 & 33.2 & 27.6 & 89.0 & 69.7 & 105.1 & 79.5 \\
Iron & $\mathrm{mg} / \mathrm{L}$ & 0.05 & 0.10 & $<0.02$ & 0.03 & $<0.02$ & $<0.02$ & $<0.02$ \\
Aluminum & $\mathrm{mg} / \mathrm{L}$ & $<0.10$ & $<0.10$ & $<0.10$ & $<0.10$ & $<0.10$ & $<0.10$ & $<0.10$ \\
Calcium & $\mathrm{mg} / \mathrm{L}$ & 1.50 & 0.60 & 0.60 & 1.20 & 1.40 & 8.30 & 4.50 \\
Lead & $\mathrm{mg} / \mathrm{L}$ & $<0.10$ & $<0.10$ & $<0.10$ & $<0.10$ & $<0.10$ & $<0.10$ & $<0.10$ \\
Magnesium & $\mathrm{mg} / \mathrm{L}$ & 0.70 & 0.30 & 0.30 & 0.30 & 0.70 & 2.50 & 0.80 \\
Nickel & $\mathrm{mg} / \mathrm{L}$ & $<0.02$ & $<0.02$ & $<0.02$ & $<0.02$ & $<0.02$ & $<0.02$ & $<0.02$ \\
Silver & $\mathrm{mg} / \mathrm{L}$ & $<0.10$ & $<0.10$ & $<0.10$ & $<0.10$ & $<0.10$ & $<0.10$ & $<0.10$ \\
COD & $\mathrm{mg} / \mathrm{L}$ & 6.48 & 4.33 & 4.32 & 17.44 & 16.28 & 2.32 & 19.76 \\
BOD & $\mathrm{mg} / \mathrm{L}$ & 6.11 & 0.94 & 3.29 & 5.64 & 4.23 & 1.87 & 3.29 \\
Dry residue & $\mathrm{mg} / \mathrm{L}$ & 200 & 60 & 16 & 16 & 80 & 100 & 112 \\
Settleable solids & $\mathrm{mg} / \mathrm{L}$ & 0.70 & 49.95 & 0.75 & 3.10 & 1.55 & 0.30 & 0.60 \\
\hline
\end{tabular}

Table 4: Analytical data of the groundwater samples collected in 10/14/1994.

\begin{tabular}{cccccccccc}
\hline Parameter & $\mathrm{Unit}$ & 1 & 2 & 3 & 4 & 5 & 6 & 7 & 8 \\
\hline Temperature & ${ }^{\circ} \mathrm{C}$ & 27 & 26 & 25 & 25 & 25 & 25 & 24 & 25 \\
$\mathrm{DO}$ & $\mathrm{mg} / \mathrm{L}$ & 3.2 & 5.8 & 7.3 & 7.3 & 6.4 & 7.4 & 7.0 & 7.0 \\
$\mathrm{pH}$ & - & 6.29 & 5.20 & 5.87 & 5.60 & 5.71 & 5.50 & 6.42 & 5.80 \\
Conductivity & $\mu \mathrm{S} / \mathrm{cm}$ & 312.0 & 50.0 & 18.7 & 107.0 & 101.0 & 103.0 & 82.0 & 49.2 \\
Iron & $\mathrm{mg} / \mathrm{L}$ & 0.80 & 0.01 & $<0.01$ & $<0.01$ & $<0.01$ & 0.04 & 0.08 & 0.01 \\
Aluminum & $\mathrm{mg} / \mathrm{L}$ & 1.07 & 0.02 & 0.01 & 0.03 & 0.02 & 0.05 & 0.37 & 0.06 \\
Calcium & $\mathrm{mg} / \mathrm{L}$ & 1.77 & 0.92 & 0.66 & 0.90 & 1.74 & 8.05 & 5.12 & 1.66 \\
Lead & $\mathrm{mg} / \mathrm{L}$ & 0.01 & 0.01 & 0.01 & 0.01 & 0.01 & 0.01 & 0.02 & 0.02 \\
Magnesium & $\mathrm{mg} / \mathrm{L}$ & 0.74 & 0.48 & 0.27 & 0.29 & 0.82 & 2.57 & 0.91 & 0.82 \\
Nickel & $\mathrm{mg} / \mathrm{L}$ & $<0.02$ & $<0.02$ & $<0.02$ & $<0.02$ & $<0.02$ & $<0.02$ & $<0.02$ & $<0.02$ \\
Silver & $\mathrm{mg} / \mathrm{L}$ & $<0.10$ & $<0.10$ & $<0.10$ & $<0.10$ & $<0.10$ & $<0.10$ & $<0.10$ & $<0.10$ \\
COD & $\mathrm{mg} / \mathrm{L}$ & 6.24 & $<1.00$ & $<1.00$ & 6.24 & 12.49 & $<1.00$ & 6.24 & $<1.00$ \\
BOD & $\mathrm{mg} / \mathrm{L}$ & $<5.0$ & $<5.0$ & $<5.0$ & $<5.0$ & 12.5 & $<5.0$ & $<5.0$ & $<5.0$ \\
Dry residue & $\mathrm{mg} / \mathrm{L}$ & 216 & 40 & 26 & 102 & 67 & 90 & 48 & 32 \\
Settleable solids & $\mathrm{mg} / \mathrm{L}$ & 0.10 & $<0.01$ & $<0.01$ & $<0.01$ & 0.10 & $<0.01$ & 0.10 & $<0.01$ \\
\hline
\end{tabular}




\section{Discussion}

The permissible concentration limits in Class 2 Brazilian fresh waters as established by National Register CONAMA 20 (published on 18 June 1986) is given in Table 5 and will be used as reference values to compare all data reported here.

Table 5: $\quad$ Permissible concentration limits in Class 2 Brazilian fresh waters established by national register CONAMA 20 published on 18 June 1986.

\begin{tabular}{ccc}
\hline PARAMETER & UNIT & VALUE \\
\hline pH & - & between 6 and 9 \\
Settleable solids & $\mathrm{mL} / \mathrm{L}$ & $<1^{\mathrm{a}}$ \\
Total Dissolved Solids $(\sim \mathrm{DR})$ & $\mathrm{mg} / \mathrm{L}$ & $<500$ \\
DO & $\mathrm{mg} / \mathrm{L}$ & $>5$ \\
BOD & $\mathrm{mg} / \mathrm{L}$ & $<5$ \\
Lead & $\mathrm{mg} / \mathrm{L}$ & $<0.03$ \\
Soluble Iron & $\mathrm{mg} / \mathrm{L}$ & $<0.3$ \\
Nickel & $\mathrm{mg} / \mathrm{L}$ & $<0.025$ \\
Silver & $\mathrm{mg} / \mathrm{L}$ & $<0.01$ \\
Aluminum & $\mathrm{mg} / \mathrm{L}$ & $<0.1$ \\
\hline
\end{tabular}

${ }^{\mathrm{a}}$ For the release of effluents.

The highest value found for the settleable solids corresponded to $383 \mathrm{mg} / \mathrm{L}$ (Table 2). Under the most pessimistic assumption, if they would have the water density $(1 \mathrm{~g} / \mathrm{mL})$, then, it would be possible estimate $0.38 \mathrm{~mL} / \mathrm{L}$ for the settleable solids that is below the guidance value of $1 \mathrm{~mL} / \mathrm{L}$ for this parameter (Table 5).

The total dissolved solids exceeded the CONAMA guideline values in one sampling campaign (September 1993) of monitoring well 4, however, it is within the analytical uncertainty of the technique (10-15\%). The conductivity was always higher at bore 1 in all sampling campaigns. In general, higher total dissolved solids content also imply on more elevated conductivity values in water bodies and such trend was verified at bore 1 in the last two monitoring programs.

The National Register CONAMA 20 did not establish guidance levels for calcium and magnesium. The highest $\mathrm{Ca}$ and $\mathrm{Mg}$ contents were found at monitoring well 6 , respectively, 8.0-8.3 mg/L and 2.3-2.6 mg/L. No health-based guideline value is proposed for hardness due to $\mathrm{Ca}$ and $\mathrm{Mg}$ in drinking-water by WHO [10]. Depending on the interaction of other factors, such as $\mathrm{pH}$ and alkalinity, water with hardness above approximately $200 \mathrm{mg} / \mathrm{L}$ may cause scale deposition in the treatment works, distribution system and pipework and tanks within buildings [10]. The data reported here are well below this value.

Some $\mathrm{pH}$ values are lower than the minimum of 6 , as given in Table 5, and could be attributed to occasional anthropogenic inputs. The lowest value was 5.2 at monitoring well 2, whose sampling occurred in October 1994. However, the 
low values of conductivity $(50 \mu \mathrm{S} / \mathrm{cm})$ and dry residue $(40 \mathrm{mg} / \mathrm{L})$ in this bore do not favor the enhanced presence of the cation $\mathrm{Na}^{+}$and anions $\mathrm{SO}_{4}{ }^{2-}$ and $\mathrm{Cl}^{-}$, which are potentially important to affect the area. On the other hand, this groundwater facies reflects the composition of rainwater with small amounts of silica added from contact with the aquifer. Such pattern of chemical data is not much amenable to plot on a standard Piper diagram [11], because there is a lack of the preponderance of typical anions and cations, and the mixed character is commonly identified. The rainwater interaction with the weathered mantle developed over Pirambóia Formation when it enters the aquifer by percolating through the unsaturated zone until it meets the water table constitutes a reasonable explanation for the low $\mathrm{pH}$ values, because the $\mathrm{pH}$ of several soil suspensions representative of horizons from three pedological profiles was determined both in water and in $\mathrm{KCl}$ solution and the most of the obtained values are strongly acid $(\mathrm{pH}<4.5)$ or moderately acid $(\mathrm{pH}$ between 4.5 and 5.5) [12].

The CONAMA guideline level for dissolved oxygen was based on a criterion for the maintenance of the aquatic life in surface water bodies (Table 5). Several DO values are lower than the minimum of $5 \mathrm{mg} / \mathrm{L}$, as given in Tables 2-4, demonstrating no pronounced aeration during sampling that is a typical situation expected in groundwater resources.

The BOD exceeded the CONAMA guideline value in the following circumstances: all bores (September 1993), monitoring wells 1 and 4 (March 1994) and bore 5 (October 1994). CONAMA did not establish guidance level for COD. Both the BOD and COD tests have been widely adopted as a measure of pollution effect based on the relative oxygen-depletion due to a waste contaminant. The BOD test measures the oxygen demand of biodegradable pollutants whereas the COD test measures the oxygen demand of biodegradable pollutants plus the oxygen demand of non-biodegradable oxidizable pollutants [13]. Despite there is no generalized correlation between BOD and COD, it is possible to develop it in some cases like verified for the groundwater samples collected in September 1993 (Fig. 3). Such relationship suggests that aerobic biological organisms are breaking down organic material present in the aquifer system following a proportion related to its abundance.

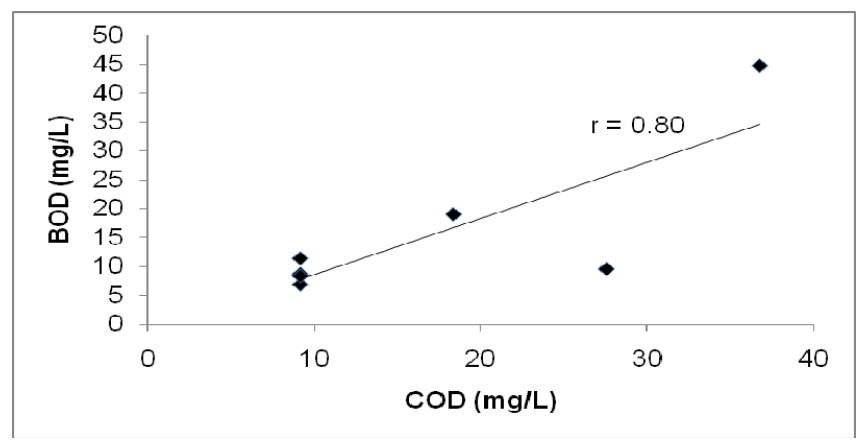

Figure 3: The relationship between BOD and COD in groundwater samples collected in September 1993. 
The Ag detection limit $(0.10 \mathrm{mg} / \mathrm{L})$ in all sampling campaigns was above the CONAMA guidance level $(0.01 \mathrm{mg} / \mathrm{L})$. $\mathrm{Ni}$ exceeded the reference value in one sampling campaign (September 1993) of monitoring well 3, without a reasonable explanation. The $\mathrm{Pb}$ detection limit $(0.10 \mathrm{mg} / \mathrm{L})$ in the sampling campaigns held in September 1993 and March 1994 was above the CONAMA guideline value $(0.03 \mathrm{mg} / \mathrm{L})$. However, $\mathrm{Pb}$ was always below this reference value in the sampling campaign held in October 1994.

Fe always exceeded the CONAMA guidance level in monitoring well 1 , the same occurring with $\mathrm{Al}$ in the sampling campaigns held in the wettest seasons (September 1993 and October 1994). Groundwater providing from this borehole often exhibited high turbidity possibly caused by some pre-filter leakage. Such assumption is reinforced by the enhanced $\mathrm{Fe}$ and $\mathrm{Al}$ contents in bore 1 relatively to others, as well by its location up-flow of the waste disposal/treatment area (Fig. 2). However, some anthropogenic inputs of these constituents are evidenced at monitoring well 7 during the sampling campaigns held in the wettest seasons, when the water table raised. This is supported by the fact that bore 7 was situated down-flow of the waste disposal/treatment area in a zone dominated by higher permeability and lower hydraulic gradient.

\section{Conclusion}

Hydrogeochemical monitoring held in eight bores drilled for characterizing the subsurface flow in a waste disposal/treatment area coupled to the development of Sand mining activities in São Paulo State, Brazil, allowed identify some anthropogenic inputs. $\mathrm{BOD}, \mathrm{Fe}$ and $\mathrm{Al}$ contents in several groundwater samples have exceeded the permissible concentration limits in Class 2 Brazilian fresh waters as established by National Register CONAMA 20 published on 18 June 1986). The enhanced levels of these parameters is possibly related to the use of several organic and inorganic chemicals for the treatment of natural sand, which have generated mine tailings able to pollute the aquifer system occurring in the area. The BOD, Fe and Al levels decreased from September 1993 to October 1994 at a monitoring well situated in a zone dominated by higher permeability and lower hydraulic gradient. However, further monitoring programs would be needed for clarifying if the concentration decrease has been caused by natural attenuation processes, different rainfall regime, human action or others factors. This is because the site is located at the recharge area of Guarani aquifer and can also contaminate some tributaries from Corumbataí River, which are very important hydrological resources in the region.

\section{References}

[1] IG (Instituto Geológico), Formações geológicas de superfície-Folha Geológica de Corumbatai-Fl. SF-23-Y-A-12, 1:50000. Instituto Geológico, São Paulo, 1984.

[2] IPT (Instituto de Pesquisa Tecnológica do Estado de São Paulo), Mapa Geológico do Estado de São Paulo. São Paulo, Monografias, 1981. 
[3] Tandel, R.Y., Caracterização do arenito Pirambóia da Fazenda São João em Analândia, SP, e sua utilização industrial, USP, São Paulo, 75 pp., 1993.

[4] Penteado, M.M., Geomorfologia do setor centro-ocidental da Depressão Periférica paulista. Série teses e monografias, 22, IGEOG/USP, São Paulo, 1976.

[5] França, A.B. \& Potter, P.E., Stratigraphy, Depositional Environment and Reservoir Analysis from Itararé Group, Paraná basin (Part 1). Petrobrás Geociences Bulletin, 2 (2/4), pp. 147-192, 1988.

[6] Lecomte, P., Stone line profiles: importance in geochemical exploration, J. Geochem. Explor., 30, pp. 35-61, 1988.

[7] APHA (American Public Health Association), Standard methods for the examination of water and wastewater. $17^{\text {th }}$ edn, Washington, 1989.

[8] HACH, Water Analysis Handbook, $2^{\text {nd }}$ edn, Hach Company: Loveland, 1992.

[9] Nollet, L.M.L., Handbook of Water Analysis, $2^{\text {nd }}$ edn, Taylor \& Francis Group: New York, 2007.

[10] Guidelines for drinking water quality; WHO (World Health Organization), Online. www.who.int/water_sanitation_health/dwq/gdwq3/en/

[11] Piper, A.M., A graphic procedure in the geochemical interpretation of water analyses, Trans.Amer.Geophysical Union, 25, pp.914-928, 1944.

[12] Jiménez-Rueda, J.R., Comments about some mineralogical data and $\mathrm{pH}$ values of soil suspensions from Pirambóia Formation, 1994.

[13] Sawyer, C.N., McCarty, P.L. \& Parkin, G.F., Chemistry for Environmental Engineering and Science, $5^{\text {th }}$ edn, McGraw-Hill: New York, 2003. 